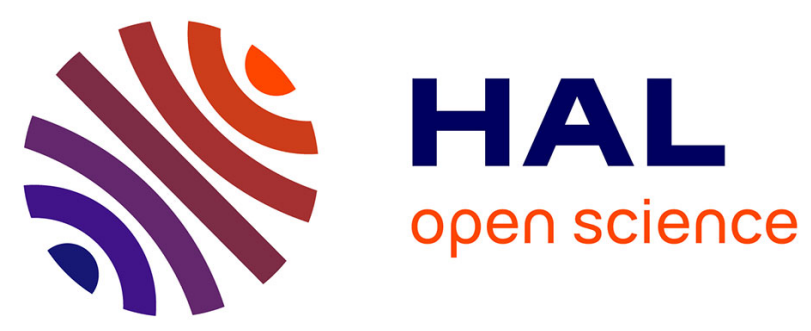

\title{
Synthesis of Er5(BO3)2F9 and Properties of RE5(BO3)2F9 (RE = Er, Yb)
}

Hubert Huppertz, Almut Haberer, Reinhard Kaindl, Jürgen Konzett, Robert Glaum

\section{- To cite this version:}

Hubert Huppertz, Almut Haberer, Reinhard Kaindl, Jürgen Konzett, Robert Glaum. Synthesis of Er5(BO3)2F9 and Properties of RE5(BO3)2F9 (RE = Er, Yb). Journal of Inorganic and General Chemistry / Zeitschrift für anorganische und allgemeine Chemie, 2010, 636 (7), pp.1326. 10.1002/zaac.201000085 . hal-00599859

\section{HAL Id: hal-00599859 \\ https://hal.science/hal-00599859}

Submitted on 11 Jun 2011

HAL is a multi-disciplinary open access archive for the deposit and dissemination of scientific research documents, whether they are published or not. The documents may come from teaching and research institutions in France or abroad, or from public or private research centers.
L'archive ouverte pluridisciplinaire $\mathbf{H A L}$, est destinée au dépôt et à la diffusion de documents scientifiques de niveau recherche, publiés ou non, émanant des établissements d'enseignement et de recherche français ou étrangers, des laboratoires publics ou privés. 


\section{Synthesis of Er5(BO3)2F9 and Properties of RE5(BO3)2F9 $(R E=E r, Y b)$}

\begin{tabular}{|c|c|}
\hline Journal: & Zeitschrift für Anorganische und Allgemeine Chemie \\
\hline Manuscript ID: & zaac.201000085.R1 \\
\hline Wiley - Manuscript type: & Article \\
\hline $\begin{array}{r}\text { Date Submitted by the } \\
\text { Author: }\end{array}$ & 09-Mar-2010 \\
\hline Complete List of Authors: & $\begin{array}{l}\text { Huppertz, Hubert; Leopold-Franzens-Universitaet Innsbruck, } \\
\text { Institut fuer Allgemeine, Anorganische und Theoretische Chemie } \\
\text { Haberer, Almut; Leopold-Franzens-Universitaet Innsbruck, Institut } \\
\text { fuer Allgemeine, Anorganische und Theoretische Chemie } \\
\text { Kaindl, Reinhard; Leopold-Franzens-Universitaet Innsbruck, Institut } \\
\text { für Mineralogie und Petrographie } \\
\text { Konzett, Jürgen; Leopold-Franzens-Universitaet Innsbruck, Institut } \\
\text { für Mineralogie und Petrographie } \\
\text { Glaum, Robert; Universität Bonn, Institut für Anorganische Chemie }\end{array}$ \\
\hline Keywords: & Erbium fluoride oxide, High-pressure, Crystal structure \\
\hline
\end{tabular}

\section{scholarONE" \\ Manuscript Central}




\title{
Synthesis of $\operatorname{Er}_{5}\left(\mathrm{BO}_{3}\right)_{2} \mathrm{~F}_{9}$ and Properties of $R E_{5}\left(\mathrm{BO}_{3}\right)_{2} \mathrm{~F}_{9}(R E=\mathrm{Er}, \mathrm{Yb})$
}

\author{
Almut Haberer ${ }^{[a]}$, Reinhard Kaindl ${ }^{[b]}$, Jürgen Konzett ${ }^{[b]}$, Robert Glaum ${ }^{[c]}$, and Hubert \\ Huppertz*[a]
}

Dedicated to Professor Rüdiger Kniep on the Occasion of His $65^{\text {th }}$ Birthday

Keywords: Erbium fluoride oxide; High-pressure; Crystal structure

$\mathrm{Er}_{5}\left(\mathrm{BO}_{3}\right)_{2} \mathrm{~F}_{9}$ was synthesized under conditions of $3 \mathrm{GPa}$ and $800{ }^{\circ} \mathrm{C}$ lattice parameters $a=2031.2(4) \mathrm{pm}, b=609.5(2) \mathrm{pm} c=$ in a Walker-type multianvil apparatus. The crystal structure was $824.6(2)$ pm, and $\beta=100.29(3)^{\circ}$. The physical properties of determined on the basis of single-crystal $\mathrm{X}$-ray diffraction data, $R E_{5}\left(\mathrm{BO}_{3}\right)_{2} \mathrm{~F}_{9}(R E=\mathrm{Er}$, Yb) including high temperature behaviour collected at room temperature. $\mathrm{Er}_{5}\left(\mathrm{BO}_{3}\right)_{2} \mathrm{~F}_{9}$ is isotypic to the and single crystal IR-/ Raman spectroscopy were investigated. recently synthesized $\mathrm{Yb}_{5}\left(\mathrm{BO}_{3}\right)_{2} \mathrm{~F}_{9}$ and crystallizes in $C 2 / c$ with the

\footnotetext{
* Univ.-Prof. Dr. Hubert Huppertz

Email: Hubert.Huppertz@uibk.ac.at

[a] Institut für Allgemeine, Anorganische und Theoretische

Đ Chemie

Leopold-Franzens-Universität Innsbruck Innrain 52a

6020 Innsbruck, Austria

[b] Institut für Mineralogie und Petrographie

Leopold-Franzens-Universität Innsbruck

Innrain 52

6020 Innsbruck, Austria

[c] Institut für Anorganische Chemie

Universität Bonn

Gerhard-Domagk-Str. 1

53121 Bonn, Germany
}

\section{Introduction}

In the past years, the field of rare-earth fluorido- and fluoride borates could be greatly extended by the application of high-pressure / high-temperature techniques, leading to the new compounds $\mathrm{Yb}_{5}\left(\mathrm{BO}_{3}\right)_{2} \mathrm{~F}_{9}$ [1], $\mathrm{Pr}_{4} \mathrm{~B}_{3} \mathrm{O}_{10} \mathrm{~F}$ [2], and $\mathrm{Gd}_{4} \mathrm{~B}_{4} \mathrm{O}_{11} \mathrm{~F}_{2}$ [3].

Before we started our high-pressure / high-temperature research, rare-earth fluorido- and fluoride borates were only represented by the compounds $R E_{3}\left(\mathrm{BO}_{3}\right)_{2} \mathrm{~F}_{3}(R E=\mathrm{Sm}, \mathrm{Eu}$, Gd) [4] and $\mathrm{Gd}_{2}\left(\mathrm{BO}_{3}\right) \mathrm{F}_{3}$ [5], synthesized by heating a stoichiometric mixture of $R E_{2} \mathrm{O}_{3}, \mathrm{~B}_{2} \mathrm{O}_{3}$, and $R E \mathrm{~F}_{3}$ under ambient pressure conditions. There is a close relationship between these two structure-types and the recently discovered high-pressure ytterbium fluoride borate $\mathrm{Yb}_{5}\left(\mathrm{BO}_{3}\right)_{2} \mathrm{~F}_{9}$ [1]. All three compounds can be described via alternating layers of the formal compositions " $R E \mathrm{BO}_{3}$ " and " $R E \mathrm{~F}_{3}$ " in the $b c$-plane. It should be emphasized that the crystal structures of the actual compounds $R E \mathrm{BO}_{3}$ and $R E \mathrm{~F}_{3}$ can not be compared with the structures of the layers, so that " $R E \mathrm{BO}_{3}$ " and " $R E \mathrm{~F}_{3}$ " only stand for the formal composition of the layers. We are now trying to substitute the $\mathrm{Yb}^{3+}$ ions of $\mathrm{Yb}_{5}\left(\mathrm{BO}_{3}\right)_{2} \mathrm{~F}_{9}$ with other rare-earth cations to yield isotypic $R E_{5}\left(\mathrm{BO}_{3}\right)_{2} \mathrm{~F}_{9}$ phases, different structures, or new compositions dependent of the size of the rare-earth ion.
$E . g$, during our studies of high-pressure phases of the rareearth borates, the compounds $R E_{4} \mathrm{~B}_{6} \mathrm{O}_{15}(R E=\mathrm{Dy}, \mathrm{Ho})$ [6-8] were intensively investigated. Nevertheless, it was not possible to obtain isotypical compounds with $R E=\mathrm{Er}, \mathrm{Tm}$, $\mathrm{Yb}$, or Lu. For these rare-earth elements, high-pressure / high-temperature experiments always yielded the compounds $R E_{3} \mathrm{~B}_{5} \mathrm{O}_{12}(R E=\mathrm{Er}-\mathrm{Lu})$ [9].

In analogy to these investigations of the rare-earth borates, we are trying to define the formation region for the composition $R E_{5}\left(\mathrm{BO}_{3}\right)_{2} \mathrm{~F}_{9}$. While $\mathrm{Yb}_{5}\left(\mathrm{BO}_{3}\right)_{2} \mathrm{~F}_{9}$ was synthesized at $7.5 \mathrm{GPa}[1]$, an isotypic erbium fluoride borate $\mathrm{Er}_{5}\left(\mathrm{BO}_{3}\right)_{2} \mathrm{~F}_{9}$ could be obtained now at a pressure of 3 $\mathrm{GPa}$. This indicates that there is a large pressure region for the formation of these high-pressure phases and the application of similar synthetic conditions to neighbouring rare-earth elements could thus lead to additional isotypic compounds. Since it was possible to obtain $\operatorname{Er}_{5}\left(\mathrm{BO}_{3}\right)_{2} \mathrm{~F}_{9}$, the existence of an isotypic thulium compound is more than likely. Future studies will show, if the synthesis with larger rare-earth cations is possible as well and at which point we observe the formation of another structure type as in the borate case. However, experiments on $\mathrm{Yb}_{5}\left(\mathrm{BO}_{3}\right)_{2} \mathrm{~F}_{9}$ at higher pressures $(10 \mathrm{GPa})$ resulted already in the formation of an apatite-structured compound, wherein all boron atoms showed a fourfold coordination [10].

In this paper, we present the synthesis and structural details of $\mathrm{Er}_{5}\left(\mathrm{BO}_{3}\right)_{2} \mathrm{~F}_{9}$ in comparison to the isotypic phase $\mathrm{Yb}_{5}\left(\mathrm{BO}_{3}\right)_{2} \mathrm{~F}_{9}$. Furthermore, several physical properties of the compounds $R E_{5}\left(\mathrm{BO}_{3}\right)_{2} \mathrm{~F}_{9}(R E=\mathrm{Er}, \mathrm{Yb})$ are reported.

\section{Experimental Section}

To synthesize the compound $\mathrm{Er}_{5}\left(\mathrm{BO}_{3}\right)_{2} \mathrm{~F}_{9}$, high-pressure / hightemperature conditions of $3 \mathrm{GPa}$ and $800{ }^{\circ} \mathrm{C}$ were applied, starting from $\mathrm{Er}_{2} \mathrm{O}_{3}$ (Strem Chemicals, 99.9\%), $\mathrm{B}_{2} \mathrm{O}_{3}$ (Strem Chemicals, 99.9+\%), and $\mathrm{ErF}_{3}$ (Strem Chemicals, 99.+\%) at equal molar ratios. The starting materials were ground up and filled into a boron nitride crucible (Henze BNP GmbH, HeBoSint ${ }^{\circledR}$ S100, Kempten, 
Germany). The compounds were compressed and heated via a multianvil assembly, based on a Walker-type module and a 1000 ton press (both devices from the company Voggenreiter, Mainleus, Germany). Eight tungsten carbide cubes (TSM-20, Ceratizit, Reutte, Austria) compressed the boron nitride crucible, which was positioned inside the centre of an 18/11 assembly. A detailed description of the assembly can be found in reference [11].

The $18 / 11$ assembly was compressed up to $3 \mathrm{GPa}$ in $1.25 \mathrm{~h}$ and heated to $800{ }^{\circ} \mathrm{C}$ (cylindrical graphite furnace) in the following 10 min, kept there for $20 \mathrm{~min}$, and cooled down to $600{ }^{\circ} \mathrm{C}$ in $20 \mathrm{~min}$ at constant pressure. After natural cooling down to room temperature by switching off the heating, a decompression period of 3.75 hours was required. Then the recovered octahedral pressure medium (MgO, Ceramic Substrates \& Components Ltd., Newport, Isle of Wight, UK) was broken apart and the sample carefully separated from the surrounding graphite and boron nitride. Pink air- and water-resistant crystals of $\mathrm{Er}_{5}\left(\mathrm{BO}_{3}\right)_{2} \mathrm{~F}_{9}$ were obtained.

\section{Crystal Structure Analysis}

The sample was characterized by powder X-ray diffraction, which was performed in transmission geometry on a flat sample of the reaction product, using a STOE STADI P powder diffractometer with $\mathrm{Mo} K_{\alpha 1}$ radiation (Ge monochromator, $\lambda=71.073 \mathrm{pm}$ ). The powder pattern showed reflections of $\mathrm{Er}_{5}\left(\mathrm{BO}_{3}\right)_{2} \mathrm{~F}_{9}$ and of $\mu-\mathrm{ErBO}_{3}$ [12] as a by-product of the synthesis (Figure 1). The experimental powder pattern tallied well with the theoretical pattern of $\mathrm{Er}_{5}\left(\mathrm{BO}_{3}\right)_{2} \mathrm{~F}_{9}$, simulated from single-crystal data. Indexing the reflections of the erbium fluoride borate, we got the parameters $a=$ 2033.0(3) pm, $b=610.6(3) \mathrm{pm}$, and $c=825.5(4) \mathrm{pm}$, with $\beta=$ $100.29(6)^{\circ}$ and a volume of 1008.2(9) $\AA^{3}$. This confirmed the lattice parameters, obtained from single-crystal X-ray diffraction (Table 1).

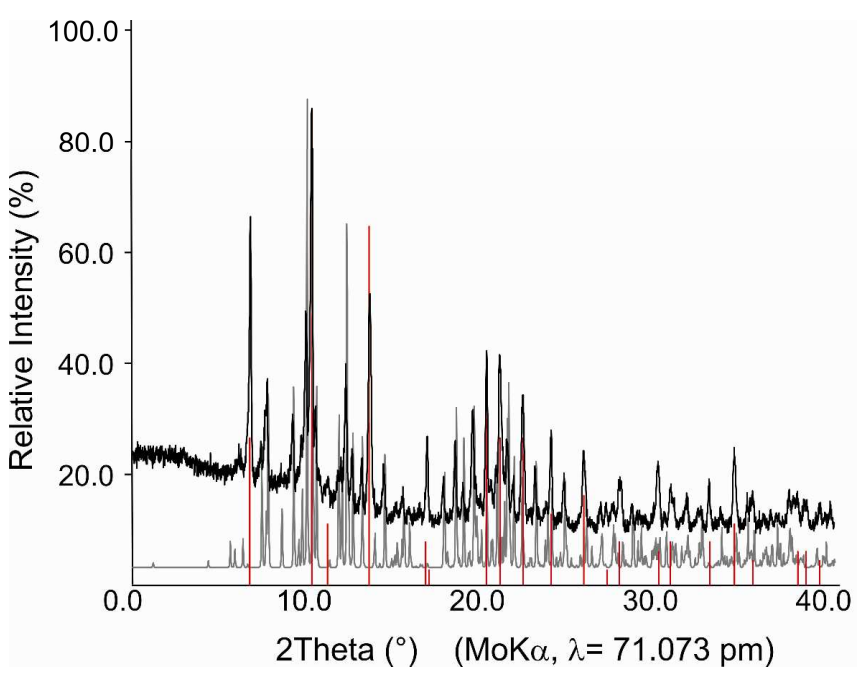

Figure 1. Experimental powder pattern of $\operatorname{Er}_{5}\left(\mathrm{BO}_{3}\right)_{2} \mathrm{~F}_{9}$ in comparison to the theoretical powder pattern beneath, based on single-crystal diffraction data. Reflections of $\mu$-ErBO 3 are marked with lines.

Intensity data of a single-crystal of $\mathrm{Er}_{5}\left(\mathrm{BO}_{3}\right)_{2} \mathrm{~F}_{9}$ were collected at room temperature by use of a Kappa CCD diffractometer (Bruker AXS / Nonius, Karlsruhe), equipped with a Miracol Fiber Optics Collimator and a Nonius FR590 generator (graphitemonochromatized $\operatorname{Mo} K_{\alpha 1}$ radiation, $\lambda=71.073 \mathrm{pm}$ ). An absorption correction, based on multi-scans [13], was applied to the data set.
All relevant details of the data collection and evaluation are listed in Table 1 .

Table 1. Crystal data and structure refinement of $\mathrm{Er}_{5}\left(\mathrm{BO}_{3}\right)_{2} \mathrm{~F}_{9}$

\begin{tabular}{|c|c|}
\hline Empirical Formula & $\mathrm{Er}_{5}\left(\mathrm{BO}_{3}\right)_{2} \mathrm{~F}_{9}$ \\
\hline Molar mass $\left(\mathrm{g} \cdot \mathrm{mol}^{-1}\right)$ & 1124.92 \\
\hline Crystal system & monoclinic \\
\hline Space group & $C 2 / c($ No. 15$)$ \\
\hline \multicolumn{2}{|c|}{ Lattice parameters from powder data } \\
\hline Powder diffractometer & STOE STADI P \\
\hline Radiation & $\operatorname{Mo}_{\alpha 1}(\lambda=71.073 \mathrm{pm})$ \\
\hline$a(\mathrm{pm})$ & $2033.0(3)$ \\
\hline$b(\mathrm{pm})$ & $610.6(3)$ \\
\hline$c(\mathrm{pm})$ & $825.5(4)$ \\
\hline$\beta(\mathrm{deg})$ & $100.29(6)$ \\
\hline Volume $\left(\AA^{3}\right)$ & $1008.2(9)$ \\
\hline \multicolumn{2}{|l|}{ Single-crystal data } \\
\hline Single-crystal diffractometer & $\begin{array}{l}\text { Bruker AXS / Nonius Kappa } \\
\text { CCD }\end{array}$ \\
\hline Radiation & $\operatorname{Mo} K_{\alpha 1}(\lambda=71.073 \mathrm{pm})$ \\
\hline$a(\mathrm{pm})$ & $2031.2(4)$ \\
\hline$b(\mathrm{pm})$ & $609.5(2)$ \\
\hline$c(\mathrm{pm})$ & $824.6(2)$ \\
\hline$\beta(\mathrm{deg})$ & $100.29(3)$ \\
\hline Volume $\left(\AA^{3}\right)$ & $1004.4(3)$ \\
\hline Formula units per cell & 4 \\
\hline Temperature $(\mathrm{K})$ & 293(2) \\
\hline Calculated density $\left(\mathrm{g} \cdot \mathrm{cm}^{-3}\right)$ & 7.44 \\
\hline Crystal size $\left(\mathrm{mm}^{3}\right)$ & $0.03 \times 0.02 \times 0.02$ \\
\hline Absorption coefficient $\left(\mathrm{mm}^{-1}\right)$ & 41.49 \\
\hline$F(000)$ & 1916 \\
\hline$\theta$ range $(\mathrm{deg})$ & $2.0 \leq \theta \leq 37.9$ \\
\hline Range in $h k l$ & $-33 / 34, \pm 10,-14 / 12$ \\
\hline Total no. reflections & 7955 \\
\hline Independent reflections & $2700\left(R_{\mathrm{int}}=0.0382\right)$ \\
\hline Reflections with $\mathrm{I}>2 \sigma(\mathrm{I})$ & $2315\left(R_{\sigma}=0.0389\right)$ \\
\hline Data / parameters & $2700 / 102$ \\
\hline Absorption correction & Multi-scan [13] \\
\hline Goodness-of-fit $\left(\mathrm{F}^{2}\right)$ & 1.062 \\
\hline \multirow[t]{2}{*}{ Final $R$ indices $(\mathrm{I}>2 \sigma(\mathrm{I}))$} & $R 1=0.0289$ \\
\hline & $w R 2=0.0530$ \\
\hline \multirow[t]{2}{*}{$R$ indices (all data) } & $R 1=0.0384$ \\
\hline & $w R 2=0.0558$ \\
\hline $\begin{array}{l}\text { Largest differ. peak / deepest } \\
\text { hole }\left(\mathrm{e} / \AA^{-3}\right)\end{array}$ & $2.71 /-2.55$ \\
\hline
\end{tabular}

The structure solution and the parameter refinement (full-matrix least-squares against $\mathrm{F}^{2}$ ) were successfully performed, using the SHELX-97 software suite $[14,15]$ with anisotropic atomic displacement parameters for all atoms. According to the systematic extinctions, the orthorhombic space groups $C 2 / c$ and $C c$ were derived. The structure solution in $C 2 / c$ (no. 15) succeeded. The final difference Fourier syntheses did not reveal any significant residual peaks in all refinements. The positional parameters of the refinements, anisotropic displacement parameters, interatomic distances, and interatomic angles are listed in the Tables 2-5. Further information of the crystal structure is available from the Fachinformationszentrum Karlsruhe (crysdata@fiz-karlsruhe.de), D-76344 Eggenstein-Leopoldshafen (Germany), by quoting the Registry No. CSD-421469. 
Table 2. Atomic coordinates and isotropic equivalent displacement parameters $\left(U_{\mathrm{eq}} / \AA^{2}\right)$ for $\mathrm{Er}_{5}\left(\mathrm{BO}_{3}\right)_{2} \mathrm{~F}_{9}$ (space group: $\left.C 2 / c\right)$. Wyckoff sites are $4 e$ for $\mathrm{Er} 3$ and $\mathrm{F} 3$ and $8 f$ for all other atoms. $U_{\text {eq }}$ is defined as one-third of the trace of the orthogonalized $U_{\mathrm{ij}}$ tensor.

\begin{tabular}{lllll}
\hline Atom & $\mathrm{x}$ & $\mathrm{y}$ & $\mathrm{z}$ & $U_{e q}$ \\
\hline Er1 & $0.30661(2)$ & $0.11935(3)$ & $0.18057(2)$ & $0.00619(5)$ \\
Er2 & $0.39031(2)$ & $0.38886(3)$ & $0.59380(2)$ & $0.00770(5)$ \\
Er3 & $1 / 2$ & $0.11138(5)$ & $1 / 4$ & $0.00783(6)$ \\
B1 & $0.3884(3)$ & $0.902(2)$ & $0.4368(8)$ & $0.014(2)$ \\
O1 & $0.4087(2)$ & $0.7605(6)$ & $0.5638(4)$ & $0.0080(6)$ \\
O2 & $0.3392(2)$ & $0.0678(7)$ & $0.4620(4)$ & $0.0123(7)$ \\
O3 & $0.4082(2)$ & $0.1054(6)$ & $0.7829(4)$ & $0.0081(6)$ \\
F1 & $0.2890(2)$ & $0.4245(5)$ & $0.0195(4)$ & $0.0089(5)$ \\
F2 & $0.3683(2)$ & $0.5761(5)$ & $0.8143(4)$ & $0.0107(5)$ \\
F3 & $1 / 2$ & $0.4892(7)$ & $1 / 4$ & $0.0134(8)$ \\
F4 & $0.2752(2)$ & $0.7781(5)$ & $0.2150(4)$ & $0.0128(6)$ \\
F5 & $0.4693(2)$ & $0.1849(6)$ & $0.5136(5)$ & $0.0192(7)$ \\
\hline
\end{tabular}

\section{Results and Discussion}

\section{Crystal Structure of $\mathrm{Er}_{5}\left(\mathrm{BO}_{3}\right)_{2} \mathrm{~F}_{9}$}

The structure of $\mathrm{Er}_{5}\left(\mathrm{BO}_{3}\right)_{2} \mathrm{~F}_{9}$ consists of isolated $\mathrm{BO}_{3}$ groups, erbium cations, and fluoride anions (Figure 2). The arrangement can be described via alternating layers of the formal compositions " $\mathrm{ErBO}_{3}$ " and " $\mathrm{ErF}_{3}$ ", spreading into the $b c$-plane. For a more detailed description of the structure, including a comparison to the related structures of $R E_{3}\left(\mathrm{BO}_{3}\right)_{2} \mathrm{~F}_{3}(R E=\mathrm{Sm}, \mathrm{Eu}, \mathrm{Gd})$ [5] and $\mathrm{Gd}_{2}\left(\mathrm{BO}_{3}\right) \mathrm{F}_{3}$ [6], the reader is referred to the description of the isotypic compound $\mathrm{Yb}_{5}\left(\mathrm{BO}_{3}\right)_{2} \mathrm{~F}_{9}$ (ref. [1]). In this paper, we briefly compare the main features of the compounds.

Table 3. Interatomic distances (pm) in $\mathrm{Er}_{5}\left(\mathrm{BO}_{3}\right)_{2} \mathrm{~F}_{9}$, calculated with the single-crystal lattice parameters.

\begin{tabular}{llllll}
\hline Er1-O2a & $231.8(4)$ & Er2-O3 & $231.2(3)$ & Er3-O1 & $232.2(4)$ \\
Er1-O2b & $232.7(4)$ & Er2-O1 & $231.6(4)$ & & $(2 \times)$ \\
Er1-O3 & $249.6(4)$ & Er2-O2 & $238.4(4)$ & Er3-O3 & $234.0(3)$ \\
Er1-O1 & $254.5(4)$ & Er2-F5 & $222.2(4)$ & & $(2 \times)$ \\
Er1-F4a & $220.9(3)$ & Er2-F2a & $225.8(3)$ & Er3-F3 & $230.3(5)$ \\
Er1-F4b & $222.4(3)$ & Er2-F2b & $227.8(3)$ & Er3-F5a & $240.8(4)$ \\
Er1-F1a & $227.6(3)$ & Er2-F1 & $233.6(3)$ & & $(2 \times)$ \\
Er1-F1b & $232.8(3)$ & Er2-F3 & $248.0(2)$ & Er3-F5b & $264.9(4)$ \\
Er1-F2 & $239.6(3)$ & Er2-F4 & $288.8(4)$ & & $(2 \times)$
\end{tabular}

\begin{tabular}{llllll}
\hline B1-O1 & $136.4(7)$ & & & & \\
B1-O3 & $139.8(7)$ & & & & \\
B1-O2 & $146.1(8)$ & $\boldsymbol{\emptyset = 1 4 0 . 8}$ & & & \\
\hline F1-Er1a & $227.6(3)$ & F2-Er2a & $225.8(3)$ & F3-Er3 & $230.3(5)$ \\
F1-Er2 & $233.6(3)$ & F2-Er2b & $227.8(3)$ & F3-Er2 & $248.0(2)$ \\
F1-Er1b & $232.8(3)$ & F2-Er1 & $239.6(3)$ & & $(2 \times)$ \\
& & & & & \\
F4-Er1a & $220.9(3)$ & F5-Er2 & $222.2(4)$ & & \\
F4-Er1b & $222.4(3)$ & F5-Er3a & $239.2(5)$ & & \\
F4-Er2 & $288.8(4)$ & F5-Er3b & $264.9(4)$ & & \\
\hline
\end{tabular}

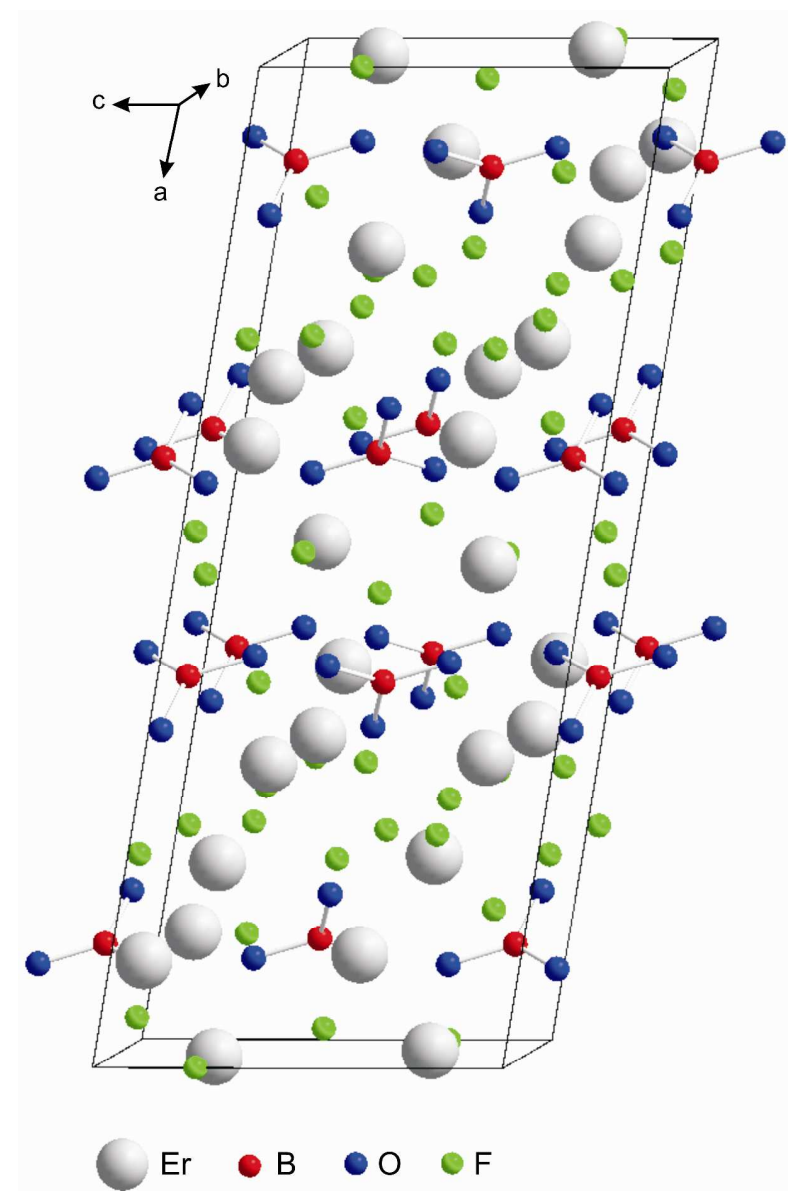

Figure 2. Crystal structure of $\mathrm{Er}_{5}\left(\mathrm{BO}_{3}\right)_{2} \mathrm{~F}_{9}$, showing isolated $\mathrm{BO}_{3^{-}}$ groups.

With $a=2031.4(2) \mathrm{pm}, b=609.5(2) \mathrm{pm}$, and $c=824.6(2)$ $\mathrm{pm}$, the lattice parameters of $\mathrm{Er}_{5}\left(\mathrm{BO}_{3}\right)_{2} \mathrm{~F}_{9}$ are slightly larger than those of $\mathrm{Yb}_{5}\left(\mathrm{BO}_{3}\right)_{2} \mathrm{~F}_{9}(a=2028.0(2), b=602.5(3)$, and $c=821.5(5) \mathrm{pm})$. This can be ascribed to the slightly larger size of $\mathrm{Er}^{3+}$ (ionic radius $=120 \mathrm{pm}$ for a ninefold coordination [16]), compared to $\mathrm{Yb}^{3+}$ (ionic radius $=118$ $\mathrm{pm}$ for coordination number nine [16]). Since the size difference is marginally, no greater deviances of the bond lengths and angles are observed. In both compounds, each of the three crystallographically independent rare-earth cations exhibits a coordination number of nine. In $\mathrm{Er}_{5}\left(\mathrm{BO}_{3}\right)_{2} \mathrm{~F}_{9}$, we find $\mathrm{Er}-\mathrm{O} / \mathrm{F}$ distances in the range of 231.2(3) - 288.8(4) pm, which tally well with the values obtained for the $\mathrm{Yb}-\mathrm{O} / \mathrm{F}$ distances in $\mathrm{Yb}_{5}\left(\mathrm{BO}_{3}\right)_{2} \mathrm{~F}_{9}$ (227.4(5) to 294.2(5) pm). Focussing on the coordination spheres of the fluoride ions, we find a coordination number of three for all fluoride ions in the two isotypic compounds. In $\mathrm{Yb}_{5}\left(\mathrm{BO}_{3}\right)_{2} \mathrm{~F}_{9}$, the $\mathrm{F}-\mathrm{Yb}$ distances are slightly shorter than the $\mathrm{F}-\mathrm{Er}$ bond lengths in $\mathrm{Er}_{5}\left(\mathrm{BO}_{3}\right)_{2} \mathrm{~F}_{9}$, which agrees with the slight size difference of the cations.

Inside the $\mathrm{BO}_{3}$-groups, the $\mathrm{B}-\mathrm{O}$ distances of $\mathrm{Er}_{5}\left(\mathrm{BO}_{3}\right)_{2} \mathrm{~F}_{9}$ vary between 136.4(7) and 146.1(8) pm (Table 3). The B$\mathrm{O}$ bond lengths tally with those in $\mathrm{Yb}_{5}\left(\mathrm{BO}_{3}\right)_{2} \mathrm{~F}_{9}$ (between 138.7(10) and 148.0(12) pm). The unusually large B-O2 bond of $148 \mathrm{pm}$, observed in $\mathrm{Yb}_{5}\left(\mathrm{BO}_{3}\right)_{2} \mathrm{~F}_{9}$, is slightly shorter in the erbium compound (146.1(8) pm), but still exeeds typical bond lengths in $\mathrm{BO}_{3}$-groups, which are 
usually in a range around $137 \mathrm{pm}$, e.g. in borates with a calcite structure $\left(\mathrm{AlBO}_{3}(137.96(4) \mathrm{pm})\right.$ [17], $\beta-\mathrm{YbBO}_{3}$ (137.8(4) pm) [18], and $\mathrm{FeBO}_{3}(137.9(2) \mathrm{pm})$ [19]).

Table 4. Interatomic angles (deg) in $\operatorname{Er}_{5}\left(\mathrm{BO}_{3}\right)_{2} \mathrm{~F}_{9}$, calculated with the single-crystal lattice parameters.

\begin{tabular}{llll}
\hline O1-B1-O3 & $125.4(5)$ & Er1a-F1-Er2 & $101.9(2)$ \\
O1-B1-O2 & $116.7(5)$ & Er1a-F1-Er1b & $110.1(2)$ \\
O3-B1-O2 & $117.9(5)$ & Er2-F1-Er1b & $145.7(2)$ \\
& $\boldsymbol{\emptyset}=\mathbf{1 2 0 . 0}$ & & $\boldsymbol{\emptyset}=\mathbf{1 1 9 . 2}$ \\
& & & \\
Er2a-F2-Er2b & $146.2(2)$ & Er3-F3-Er2a & $107.4(2)$ \\
Er2a-F2-Er1 & $100.6(2)$ & Er3-F3-Er2b & $107.4(2)$ \\
Er2b-F2-Er1 & $112.6(2)$ & Er2a-F3-Er2b & $145.1(2)$ \\
& $\boldsymbol{\emptyset}=\mathbf{1 1 9 . 8}$ & & $\boldsymbol{\emptyset}=\mathbf{1 2 0 . 0}$ \\
& & & \\
Er1a-F4-Er1b & $135.4(2)$ & Er2-F5-Er3a & $133.6(2)$ \\
Er1a-F4-Er2 & $91.0(2)$ & Er2-F5-Er3b & $104.5(2)$ \\
Er1b-F4-Er2 & $133.4(2)$ & Er3a-F5-Er3b & $118.2(2)$ \\
& $\boldsymbol{\emptyset = 1 9 9 . 9}$ & & $\boldsymbol{\emptyset}=\mathbf{1 1 8 . 8}$ \\
\hline
\end{tabular}

In analogy to $\mathrm{Yb}_{5}\left(\mathrm{BO}_{3}\right)_{2} \mathrm{~F}_{9}$, we have calculated the charge distribution of the atoms in $\mathrm{Er}_{5}\left(\mathrm{BO}_{3}\right)_{2} \mathrm{~F}_{9}$ via bond valence sums $(2 \mathrm{~V})$ with VaList (Bond Valence Calculation and Listing) [20] and with the CHARDI concept ( $2 \mathrm{Q})$ [21-23], confirming the formal valence states in the fluoride borate. Table 5 displays the results of the formal ionic charges of the atoms, which are in agreement within the limits of both concepts. In $\mathrm{Yb}_{5}\left(\mathrm{BO}_{3}\right)_{2} \mathrm{~F}_{9}$, the bond valence sums for the boron atom were extraordinarily low $(\Sigma \mathrm{V}=2.59)$, due to the large $\mathrm{B}-\mathrm{O} 2$ bond present in the structure. Since the boron bond lengths are shorter in $\operatorname{Er}_{5}\left(\mathrm{BO}_{3}\right)_{2} \mathrm{~F}_{9}$, we now obtain a better value of $\Sigma \mathrm{V}=2.73$ for $\mathrm{B} 1$. Furthermore, we have calculated the MAPLE value (Madelung Part of Lattice Energy according to Hoppe [24-26]) of $\operatorname{Er}_{5}\left(\mathrm{BO}_{3}\right)_{2} \mathrm{~F}_{9}$ to compare it with the sum of the MAPLE values for the underlying binary components, namely the high-pressure modification of $\mathrm{Er}_{2} \mathrm{O}_{3}$ [27], the ambient-pressure modification of $\mathrm{B}_{2} \mathrm{O}_{3}\left(\mathrm{~B}_{2} \mathrm{O}_{3}-\mathrm{I}\right)$ [28], and $\mathrm{ErF}_{3}$ [29]. We obtained a value of $53879 \mathrm{~kJ} / \mathrm{mol}$ in comparison to $53240 \mathrm{~kJ} / \mathrm{mol}$ (deviation: $1.2 \%$ ), starting from the binary components $\left[1 \times \mathrm{Er}_{2} \mathrm{O}_{3}(15283 \mathrm{~kJ} / \mathrm{mol})+1 \times \mathrm{B}_{2} \mathrm{O}_{3}-\mathrm{I}\right.$ $\left.(20626 \mathrm{~kJ} / \mathrm{mol})+3 \times \mathrm{ErF}_{3}(17331 \mathrm{~kJ} / \mathrm{mol})\right]$.

Table 5. Charge distribution in $\mathrm{Er}_{5}\left(\mathrm{BO}_{3}\right)_{2} \mathrm{~F}_{9}$, calculated with VaList $(2 \mathrm{~V})$ [20] and the CHARDI concept ( $\mathrm{QQ})$ [21-23].

\begin{tabular}{lllll}
\hline & Er1 & Er2 & Er3 & B1 \\
\hline$\Sigma \mathrm{V}$ & 3.09 & 2.94 & 2.70 & 2.73 \\
$\Sigma \mathrm{Q}$ & 3.06 & 2.92 & 3.05 & 3.00 \\
\hline & $\mathrm{O} 1$ & $\mathrm{O} 2$ & $\mathrm{O} 3$ & $\mathrm{~F} 1$ \\
\hline$\Sigma \mathrm{V}$ & -2.06 & -1.94 & -1.99 & -0.96 \\
$\Sigma \mathrm{Q}$ & -2.20 & -1.80 & -1.95 & -1.10 \\
\hline & $\mathrm{F} 2$ & $\mathrm{~F} 3$ & $\mathrm{~F} 4$ & $\mathrm{~F} 5$ \\
\hline$\Sigma \mathrm{V}$ & -1.01 & -0.76 & -0.93 & -0.81 \\
$\Sigma \mathrm{Q}$ & -1.14 & -0.88 & -0.91 & -0.95 \\
\hline
\end{tabular}

\section{Elemental analyses}

Since it is nearly impossible to distinguish between fluoride ions and hydroxyl groups by means of electron density or bond lengths, we performed elemental analyses on our samples of $R E_{5}\left(\mathrm{BO}_{3}\right)_{2} \mathrm{~F}_{9}(R E=\mathrm{Er}, \mathrm{Yb})$ to assure the atom assignments in both structures. EDX measurements were performed on a JEOL JSM-6500F scanning electron microscope, equipped with a field emission gun at an acceleration voltage of $16 \mathrm{kV}$. Samples were prepared by placing single crystals of both phases on adhesive conductive pads and subsequently coating them with a thin conductive carbon film. Each EDX spectrum (Oxford Instruments) was recorded with the analyzed area limited on one single crystal to avoid the influence of possibly contaminating phases. The crystals of $\mathrm{Er}_{5}\left(\mathrm{BO}_{3}\right)_{2} \mathrm{~F}_{9}$ showed average atomic compositions (theoretical values in brackets) of Er 63.1 (74.3) wt\%; B 8.9 (1.9) wt\% ; O 9.3 (8.5) wt\% ; F 18.7 (15.2) wt \%. For $\mathrm{Yb}_{5}\left(\mathrm{BO}_{3}\right)_{2} \mathrm{~F}_{9}$, average compositions (wt\%) of $\mathrm{Yb} 70.7$ (75.0) wt\% ; B 4.6 (1.9) wt\% ; O 8.4 (8.3) wt $\%$; F 16.3 (14.8) wt\% were obtained. Due to the light weight of boron, measurements have to be taken with caution, but still, these results confirm the presence of all elements and the composition, obtained from the single crystal structure determination.

Furthermore, the composition of $\mathrm{Yb}_{5}\left(\mathrm{BO}_{3}\right)_{2} \mathrm{~F}_{9}$ was confirmed by chemical analysis with a JEOL JXA-8100 electron microprobe. The sample was prepared by embedding bulk material in epoxy resin and polishing with diamond polishing paste. Analytical conditions were a 15 $\mathrm{kV}$ acceleration voltage and a $20 \mathrm{nA}$ beam current with measurement times of $40 \mathrm{sec}$ on the peaks and $20 \mathrm{sec}$ on the backgrounds of the $\mathrm{O}-K_{\alpha}, \mathrm{F}-K_{\alpha}$, and $\mathrm{Yb}-L_{\alpha} \mathrm{X}$-ray lines. $\mathrm{SiO}_{2}$, $\mathrm{Al}_{2} \mathrm{SiO}_{4} \mathrm{~F}_{2}$, and $\mathrm{Yb}_{5} \mathrm{P}_{5} \mathrm{O}_{14}$ were used as standards for $\mathrm{O}, \mathrm{F}$, and $\mathrm{Yb}$, respectively, and the raw counts were corrected with the ZAF correction procedure. Boron could not be determined quantitatively with the electron microprobe due to its low concentration. An average of 3 analyses on three different crystals yielded (theoretical values in brackets): $\mathrm{Yb}$ $74.4 \pm 0.2$ (75.0) wt\%; O $8.6 \pm 0.4$ (8.3) wt $\%$; F $14.5 \pm 0.6$ (14.8) $\mathrm{wt} \%$.

\section{Physical Properties of $R E_{5}\left(\mathrm{BO}_{3}\right)_{2} \mathrm{~F}_{9}(R E=\mathrm{Er}, \mathrm{Yb})$}

\section{UV/vis spectroscopy of $\mathrm{Yb}_{5}\left(\mathrm{BO}_{3}\right)_{2} \mathrm{~F}_{9}$}

The electronic absorption spectrum of $\mathrm{Yb}_{5}\left(\mathrm{BO}_{3}\right)_{2} \mathrm{~F}_{9}$ was measured at $293 \mathrm{~K}$ in the nir/vis/UV $\left(5800-28000 \mathrm{~cm}^{-1}\right.$, step-width $\Delta \lambda(\mathrm{UV} / \mathrm{vis})=1 \mathrm{~nm}, \Delta \lambda(\mathrm{nir})=2 \mathrm{~nm})$, using a strongly modified CARY 17 microcrystal spectrophotometer (Spectra Services, ANU Canberra, Australia). Details of the spectrometer have already been described in literature [30, 31]. A polycrystalline agglomerate with dimensions $0.2 \times$ $0.2 \times 0.05 \mathrm{~mm}^{3}$ was selected for the investigation. The noisy spectrum (Fig. 3) results from the small size and rather modest optical quality of the agglomerate. The reference intensity was measured with a pinhole instead of the crystal mounted on an aperture. The electronic absorption spectrum of a polycrystalline agglomerate of $\mathrm{Yb}_{5}\left(\mathrm{BO}_{3}\right)_{2} \mathrm{~F}_{9}$ shows the transition ${ }^{2} \mathrm{~F}_{7 / 2} \rightarrow{ }^{2} \mathrm{~F}_{5 / 2}$, expected for $\mathrm{Yb}^{3+}$ at $\tilde{v} \approx 10400 \mathrm{~cm}^{-1}$ [32]. Due to weak ligand-field interaction, the signal is split 
into a sharp peak at $\tilde{v}=10236 \mathrm{~cm}^{-1}$ and a broader shoulder at $\tilde{v}=10660 \mathrm{~cm}^{-1}$.

Figure 3. Electronic absorption spectrum of a polycrystalline agglomerate of $\mathrm{Yb}_{5}\left(\mathrm{BO}_{3}\right)_{2} \mathrm{~F}_{9}$.

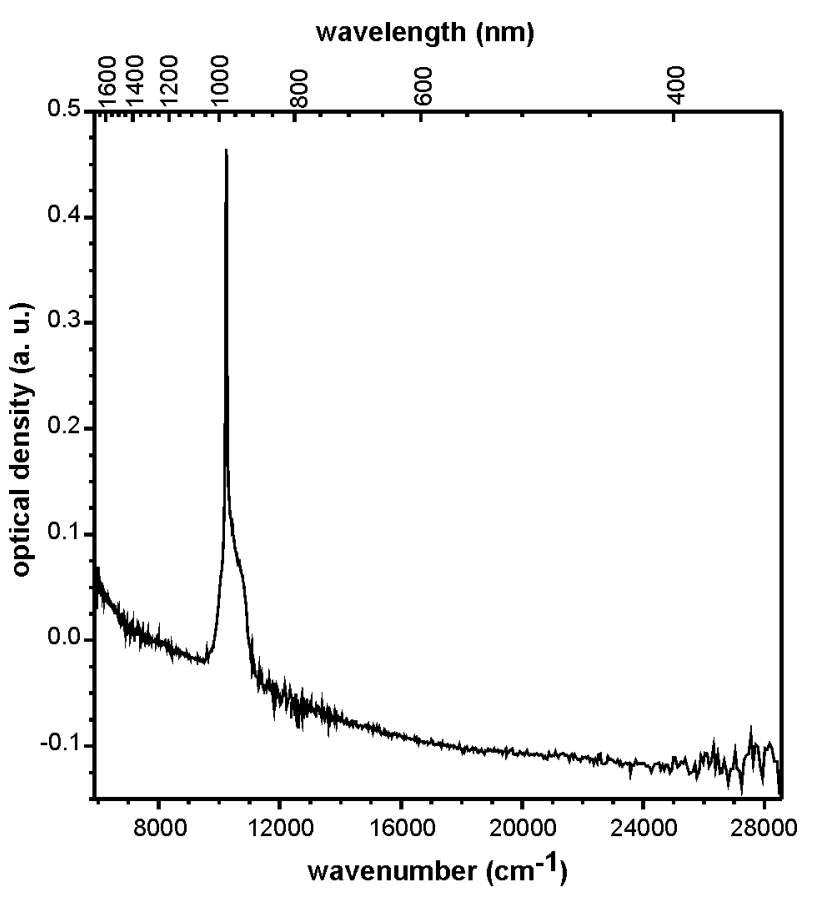

\section{IR spectroscopy}

FTIR absorbance spectra of single crystals of $R E_{5}\left(\mathrm{BO}_{3}\right)_{2} \mathrm{~F}_{9}$ $(R E=\mathrm{Er}, \mathrm{Yb})$ were measured in transmitted, polarized light on a $\mathrm{BaF}_{2}$ plate using a BRUKER VERTEX 70 spectrometer, attached to a HYPERION 3000 microscope, a MIR light source, and a LN-MCT detector. Spectral resolution was $\sim 4 \mathrm{~cm}^{-1}$. Minimum-maximum normalization was done by the OPUS 6.5 software (BRUKER). In Figure 4 , the spectra of both compounds are displayed. The absorptions of $\mathrm{Yb}_{5}\left(\mathrm{BO}_{3}\right)_{2} \mathrm{~F}_{9}$ (Fig. 4, bottom) correspond to the absorptions measured on the bulk material (Ref. [1]). In the IR-spectrum of the isotypic erbium compound (Fig. 4, top), the absorption bands are slightly shifted to higher wavelengths. The absorption patterns of the IR spectra are typical for borates exhibiting triangular $\mathrm{BO}_{3}$-groups $[1,33$, 34]. Below $600 \mathrm{~cm}^{-1}$ for $\mathrm{Yb}_{5}\left(\mathrm{BO}_{3}\right)_{2} \mathrm{~F}_{9}$ and below $650 \mathrm{~cm}^{-1}$ for $\mathrm{Er}_{5}\left(\mathrm{BO}_{3}\right)_{2} \mathrm{~F}_{9}$, bands are evoked by the in plane bending $\left(v_{4}\right)$ of the $\mathrm{BO}_{3}$-groups. The strong and usually sharp absorptions derived from the out of plane bending $\left(v_{2}\right)$ of the trigonal ion occur in the range of $600-780 \mathrm{~cm}^{-1}$ for $\mathrm{Yb}_{5}\left(\mathrm{BO}_{3}\right)_{2} \mathrm{~F}_{9}$ and $650-850 \mathrm{~cm}^{-1}$ for $\operatorname{Er}_{5}\left(\mathrm{BO}_{3}\right)_{2} \mathrm{~F}_{9}$. According to the crystalline environment, the absorption bands between $800-950 \mathrm{~cm}^{-1}$ for $\mathrm{Yb}_{5}\left(\mathrm{BO}_{3}\right)_{2} \mathrm{~F}_{9}$ and $900-1000 \mathrm{~cm}^{-1}$ for $\mathrm{Er}_{5}\left(\mathrm{BO}_{3}\right)_{2} \mathrm{~F}_{9}$ can be classified as symmetric stretching vibrations $\left(v_{1}\right)$. Asymmetric stretching vibrations $\left(v_{3}\right)$ of the $\mathrm{BO}_{3}$-groups are assigned in the areas of $1150-1400 \mathrm{~cm}^{-1}$ for $\mathrm{Yb}_{5}\left(\mathrm{BO}_{3}\right)_{2} \mathrm{~F}_{9}$ and of $1200-1500 \mathrm{~cm}^{-1}$ for $\operatorname{Er}_{5}\left(\mathrm{BO}_{3}\right)_{2} \mathrm{~F}_{9}$. Interestingly, two bands between 3400 and $3600 \mathrm{~cm}^{-1}$ were detected in the single crystal spectra of $R E_{5}\left(\mathrm{BO}_{3}\right)_{2} \mathrm{~F}_{9}(R E=$ $\mathrm{Er}, \mathrm{Yb}$ ) (Figure 5), which were not present in the corresponding spectrum of dried bulk $\mathrm{Yb}_{5}\left(\mathrm{BO}_{3}\right)_{2} \mathrm{~F}_{9}$ [1]. Bands in this range usually indicate $\mathrm{OH}$-groups in watercontaining borates. The substitution of fluoride with hydroxyl groups is a problem commonly known from fluoride borates $[3,4]$.

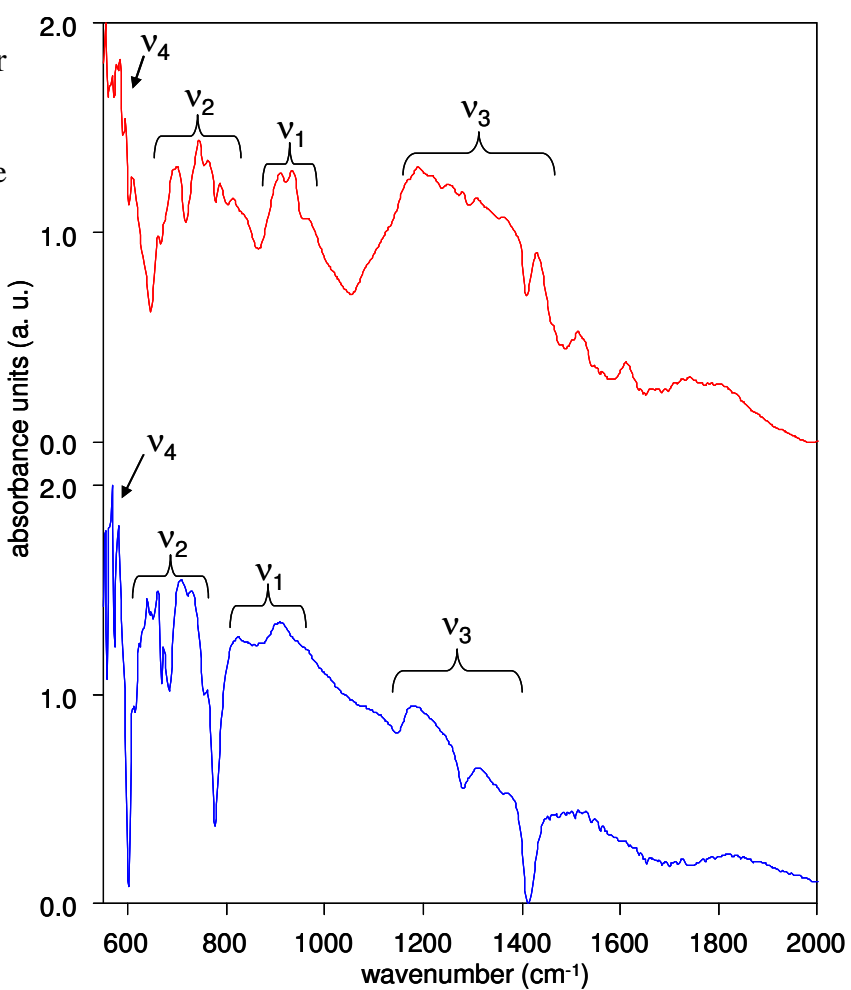

Figure 4. FTIR absorbance spectra of single crystals of $\mathrm{Er}_{5}\left(\mathrm{BO}_{3}\right)_{2} \mathrm{~F}_{9}$ (top) and $\mathrm{Yb}_{5}\left(\mathrm{BO}_{3}\right)_{2} \mathrm{~F}_{9}$ (bottom) in the range 550-2000 $\mathrm{cm}^{-1}$.

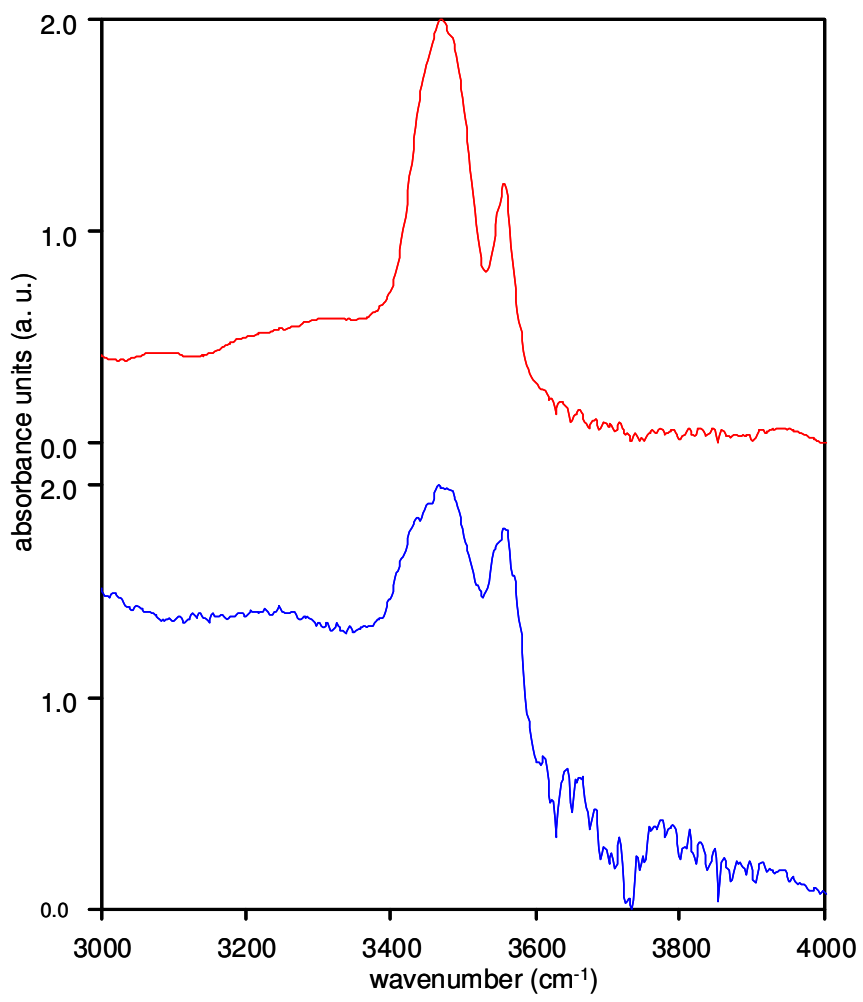

Figure 5. FTIR absorbance spectra on single crystals of $\mathrm{Er}_{5}\left(\mathrm{BO}_{3}\right)_{2} \mathrm{~F}_{9}$ (top) and $\mathrm{Yb}_{5}\left(\mathrm{BO}_{3}\right)_{2} \mathrm{~F}_{9}$ (bottom) in the range 3000 $4000 \mathrm{~cm}^{-1}$.

The single crystals, which were examined via IR spectroscopy, have been exposed to air and humidity and were not dried under high vacuum like the bulk material of 
$\mathrm{Yb}_{5}\left(\mathrm{BO}_{3}\right)_{2} \mathrm{~F}_{9}$. Thus, the exchange of fluoride with $\mathrm{OH}-$ groups occurs due to hygroscopic alteration. In apatites, the exchange of hydroxyl and fluoride ions was previously observed and studied $[35,36]$.

\section{Raman spectroscopy}

Raman spectra of single crystals of $R E_{5}\left(\mathrm{BO}_{3}\right)_{2} \mathrm{~F}_{9}(R E=\mathrm{Er}$, $\mathrm{Yb})$ were measured without polarizers in the range 100 $1600 \mathrm{~cm}^{-1}$, using a HORIBA LABRAM HR-800 confocal micro-spectrometer and a $785 \mathrm{~nm}$ diode laser. Laser focus and power on the sample surface was $\sim 1 \mu \mathrm{m}$ and $\sim 10 \mathrm{~mW}$, respectively. Depth resolution was $\sim 4 \mu \mathrm{m}$, spectral resolution $\sim 6 \mathrm{~cm}^{-1}$. Wavenumber accuracy of $\sim 3 \mathrm{~cm}^{-1}$ was achieved by regularly adjusting the zero-order position of the grating and checked by a Neon calibration lamp. Third order polynomial background subtraction, normalization and band fitting by Gauss-Lorentz functions were done by the LABSPEC 5 software (HORIBA). Some glue contamination cannot be excluded.

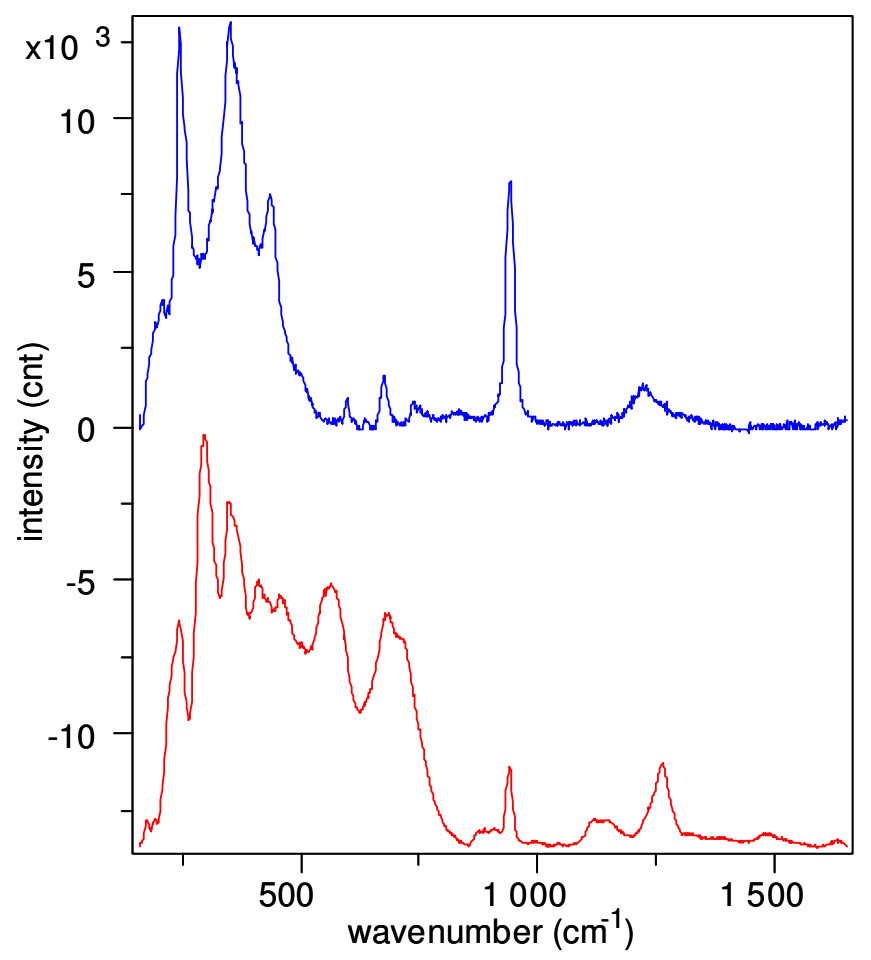

Figure 6. Raman-spectra on single crystals of $\mathrm{Yb}_{5}\left(\mathrm{BO}_{3}\right)_{2} \mathrm{~F}_{9}$ (top) and $\mathrm{Er}_{5}\left(\mathrm{BO}_{3}\right)_{2} \mathrm{~F}_{9}$ (bottom) in the range $100-1600 \mathrm{~cm}^{-1}$.

The Raman spectra of the isotypic compounds $R E_{5}\left(\mathrm{BO}_{3}\right)_{2} \mathrm{~F}_{9}(R E=\mathrm{Er}, \mathrm{Yb})$ are quite similar with the most intense bands $<500 \mathrm{~cm}^{-1}$ and the narrow, "isolated" band at $\sim 940 \mathrm{~cm}^{-1}$ (Figure 6). Above $1000 \mathrm{~cm}^{-1}$, one broad band for $\mathrm{Yb}_{5}\left(\mathrm{BO}_{3}\right)_{2} \mathrm{~F}_{9}$ and several broader bands for $\mathrm{Er}_{5}\left(\mathrm{BO}_{3}\right)_{2} \mathrm{~F}_{9}$ are observed. Bands around $900 \mathrm{~cm}^{-1}$ in borates are usually assigned to stretching modes of $\mathrm{BO}_{4}$-tetrahedra whereas $\mathrm{BO}_{3}$-groups are expected $>1100 \mathrm{~cm}^{-1}[4,37-42]$. However, in hydrated monoborates very intense bands at 882 and 501 $\mathrm{cm}^{-1}$ were observed and assigned to symmetric stretching vibrations of the isolated $\mathrm{BO}_{3}$-groups [39]. The unusually large variation of $\mathrm{B}-\mathrm{O}$ distances inside the $\mathrm{BO}_{3}$-groups (see above) might account for the comparatively low wavenumber and the large wavenumber range of these bands. Bands $<500 \mathrm{~cm}^{-1}$ can be assigned to bending and stretching vibrations of the isolated $\mathrm{BO}_{3}$-groups, $R E-\mathrm{O}, R E-$ $\mathrm{F}, \mathrm{F}-\mathrm{O}$ bonds, and lattice vibrations.

\section{Thermal behaviour of $\mathrm{Yb}_{5}\left(\mathrm{BO}_{3}\right)_{2} \mathrm{~F}_{9}$}

In situ X-ray powder diffraction experiments were done on a STOE STADI $\mathrm{P}$ powder diffractometer $\left[\mathrm{Mo} K_{\alpha 1}\right.$ radiation $(\lambda=71.073 \mathrm{pm})]$ with a computer controlled STOE furnace: The sample was enclosed in a silica capillary and heated from room temperature to $500{ }^{\circ} \mathrm{C}$ in $100{ }^{\circ} \mathrm{C}$ steps, and from $500{ }^{\circ} \mathrm{C}$ to $1100{ }^{\circ} \mathrm{C}$ in $50{ }^{\circ} \mathrm{C}$ steps. The heating rate was set to $40^{\circ} \mathrm{C} / \mathrm{min}$. Afterwards, the sample was cooled down to $500{ }^{\circ} \mathrm{C}$ in $50{ }^{\circ} \mathrm{C}$ steps, and from $500{ }^{\circ} \mathrm{C}$ to room temperature in $100{ }^{\circ} \mathrm{C}$ steps (cooling rate: $50{ }^{\circ} \mathrm{C} / \mathrm{min}$ ). After each heating step, a diffraction pattern was recorded over the angular range $3^{\circ} \leq 2 \theta \leq 40^{\circ}$. The temperature-dependent $\mathrm{X}$-ray powder diffraction experiment on $\mathrm{Yb}_{5}\left(\mathrm{BO}_{3}\right)_{2} \mathrm{~F}_{9}$ indicated a decomposition and subsequent phase changes of the decomposition products (Figure 7). Successive heating of $\mathrm{Yb}_{5}\left(\mathrm{BO}_{3}\right)_{2} \mathrm{~F}_{9}$ in the range of $650-850{ }^{\circ} \mathrm{C}$ resulted in a decomposition into a mixture of $\pi$ - $\mathrm{YbBO}_{3}$ [43] and another still unidentified phase. Further heating led to a transformation of $\pi$ - $\mathrm{YbBO}_{3}$ into the high-temperature polymorph $\mu-\mathrm{YbBO}_{3}$ [43] in the range of $900-1100{ }^{\circ} \mathrm{C}$. Additionally, reflections of $\mathrm{YbF}_{3}$ and a formation of the silicate $\mathrm{Yb}_{2} \mathrm{Si}_{2} \mathrm{O}_{7}$ [44] were observed. The latter was formed by a reaction with the silica capillary, which is known to happen occasionally. Subsequent cooling showed a complete retransformation into the low-temperature polymorph $\pi-\mathrm{YbBO}_{3}$ below $500{ }^{\circ} \mathrm{C}$. The formation and transformation of $\pi$-YbBO 3 into the high-temperature polymorph $\mu-\mathrm{YbBO}_{3}$ and back have been often observed in temperature-dependent $\mathrm{X}$-ray powder diffraction experiments of ytterbium borates, e.g. with $\mathrm{Yb}_{3} \mathrm{~B}_{5} \mathrm{O}_{12}$ [9].

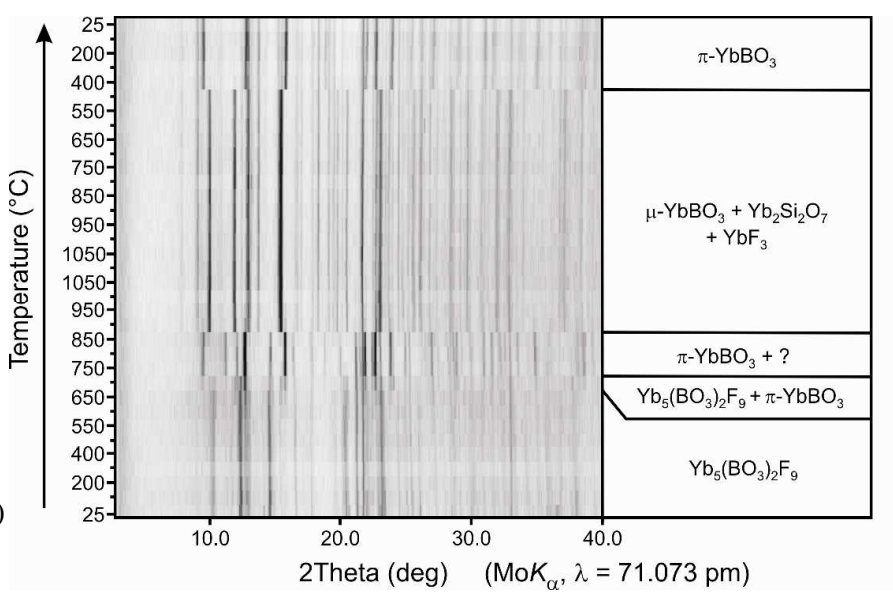

Figure 7. Temperature-dependent $\mathrm{X}$-ray powder patterns, following the decomposition reaction of $\mathrm{Yb}_{5}\left(\mathrm{BO}_{3}\right)_{2} \mathrm{~F}_{9}$.

\section{Conclusions}

The successful syntheses of $\mathrm{Yb}_{5}\left(\mathrm{BO}_{3}\right)_{2} \mathrm{~F}_{9}(7.5 \mathrm{GPa})$ and the isotypic erbium fluoride borate $\mathrm{Er}_{5}\left(\mathrm{BO}_{3}\right)_{2} \mathrm{~F}_{9}$ at a pressure of $3 \mathrm{GPa}$ suggest a large formation region for these high pressure phases. The application of similar synthetic conditions to neighbouring rare-earth elements could lead to additional isotypic compounds and will be studied in the future. However, in the case of $R E^{3+}=\mathrm{Yb}^{3+}$, experiments at higher pressures $(10 \mathrm{GPa})$ resulted in the formation of an 
apatite-structured compound, wherein all boron atoms showed a fourfold coordination [10].

\section{Acknowledgments}

We thank Dr. Gunter Heymann for collecting the single-crystal data. Special thanks go to Christian Minke (LMU Munich) for the EDX analyses.

[1] A. Haberer, H. Huppertz, J. Solid State Chem. 2009, 182, 888.

[2] A. Haberer, H. Huppertz, Solid State Sci., doi:10.1016/j.solidstatesciences.2009.12.017.

[3] A. Haberer, R. Kaindl, H. Huppertz, J. Solid State Chem. 2010, 183, 471.

[4] G. Corbel, R. Retoux, M. Leblanc, J. Solid State Chem. 1998 139, 52 .

[5] H. Müller-Bunz, Th. Schleid, Z. Anorg. Allg. Chem.. 2002, 628,2750

[6] H. Huppertz, B. von der Eltz, J. Am. Chem. Soc. 2002, 124 9376.

[7] H. Huppertz, Z. Naturforsch. 2003, B58, 278.

[8] H. Huppertz, H. Emme, J. Phys.: Condens. Matter 2004, 16, 1283.

[9] H. Emme, M. Valldor, R. Pöttgen, H. Huppertz, Chem. Mater. 2005, 17, 2707.

[10] A. Haberer, H. Huppertz, unpublished results.

[11] H. Huppertz, Z. Kristallogr. 2004, 219, 330.

[12] R. E.Newnham, M. J. Redman, R. P. Santoro, J. Am. Ceram. Soc. 1963, 46, 253.

[13] Z. Otwinowski, W. Minor, Methods Enzymol. 1997, 276, 307.

[14] G. M. Sheldrick, SHELXS-97 and SHELXL-97, Program suite for the solution and refinement of crystal structures, 1997, University of Göttingen, Göttingen, Germany.

[15] G. M. Sheldrick, Acta Crystallogr. A 2008, 64, 112.

[16] R. D. Shannon, Acta Crystallogr. 1976, A32, 751.

[17] A. Vegas, Acta Crystallogr. B 1977, 33, 3607.

[18] H. Huppertz, Z. Naturforsch. B 2001, 56, 697.

[19] R. Diehl, Solid State Commun. 1975, 17, 743.

[20] A.S. Wills, VaList Version 3.0.13, 1998-2008, University College London, UK. Program available from www.ccp14.ac.uk

[21] I.D. Brown, D. Altermatt, Acta Crystallogr. B 1985, 41, 244.

[22] N.E. Brese, M. O'Keeffe, Acta Crystallogr. B 1991, 47, 192.

[23] R. Hoppe, S. Voigt, H. Glaum, J. Kissel, H. P. Müller, K. J. Bernet, Less-Common Met. 1989, 156, 105.

[24] R. Hoppe, Angew. Chem. 1966, 78, 52-63, Angew. Chem. Int. Ed. Engl. 1966, 5, 95-106.

[25] R. Hoppe, Angew. Chem. 1970, 82, 7-16; Angew. Chem. Int. Ed. Engl. 1970, 9, 25-34.

[26] R. Hübenthal, MAPLE (version 4), program for the calculation of MAPLE values, 1993, University of Gießen, Gießen (Germany).

[27] H.R. Hoekstra, Inorg. Chem. 1966, 5, 754.

[28] S.V. Berger, Acta Crystallogr. 1952, 5, 389.

[29] A. Zalkin, D. H. Templeton, J. Am. Chem. Soc. 1953, 75, 2453.
[30] E. Krausz, Aust. J. Chem. 1993, 46, 1041.

[31] E. Krausz, AOS News 1998, 12, 21.

[32] B. Henderson, G. F. Imbusch, Optical Spectroscopy of Solids, Oxford University Press, 1989.

[33] J.P. Laperches, P. Tarte, Spectrochim. Acta 1966, 22, 1201.

[34] G. Heymann, K. Beyer, H. Huppertz, Z.Naturforsch B, 2004, $59,1200$.

[35] A. Knappwost, Naturwiss. 1959, 46, 555.

[36] V. P. Orlovskii, S. P. Ionov, T. V. Belyaevskaya, S. M. Barinov, Inorg. Mater. 2002, 38, 182.

[37] H. Emme, H. Huppertz, Chem. Eur. J. 2003, 9, 3623.

[38] H. Huppertz, J. Solid State Chem., 2004, 177, 3700.

[39] L. Jun, X. Shuping, G. Shiyang, Spectrochim. Acta A 1995, 51,519 .

[40] G. Chadeyron, M. El-Ghozzi, R. Mahiou, A. Arbus, J. C. Cousseins, J. Solid State Chem., 1997, 128, 261.

[41] J. C. Zhang, Y. H. Wang, X. Guo, J. Lumin. 2007, 122-123, 980.

[42] G. Padmaja, P. Kistaiah, J. Phys. Chem. A 2009, 113, 2397.

[43] W. F. Bradley, D. L. Graf, R. S. Roth, Acta Crystallogr. 1966, 20, 284.

[44] Y. I. Smolin, Y. F. Shepelev, Acta Crystallogr. B 1970, 26, 484.

Received: ((will be filled in by the editorial staff)) Published online: ((will be filled in by the editorial staff)) 
